KATHA, Vol. 13, 1-31 (2017)

\title{
No Sale: a history of successful failure(s) at teaching the Holocaust to Israel's Palestinian Arab citizenry, 1996 to the present.
}

\author{
Dr Andrea G. Tyndall \\ Department of History \\ Maastricht University \\ Maastricht, the Netherlands
}

\begin{abstract}
In the past 25 years, there have been three distinct efforts by Yad Vashem to teach the Holocaust to Israel's Arab citizenry. All three programs failed miserably. In this paper, I analyse these different programs so as to identify the systemic causes of Yad Vashem's sole educational failure (s) in teaching the Holocaust to its population. This paper argues that these programs were seen as failure(s) because they did not achieve the stated educational goals. This research supports the claim that these very failures were in fact successes in that they maintained the core beliefs that created the continuing conflict between Jewish and Arab citizens in the first place. These failures were, in fact, successful components in maintaining an intractable conflict between the majority and minority populations. These findings rest upon two bodies of research materials. The first is primary sources gathered from Yad Vashem and interviews conducted with key educational actors in this process. Additionally, articles and editorials from the Israeli and Arab popular presses, which helped to set public opinion on these programs, were examined. This research is important in understanding the conflict between two civic groups who sufferred from 'the narcissism of minor differences'. This gives hope for the existence of peace.
\end{abstract}

Keywords: Holocaust education; Arab/Israeli conflict; Arab education; Conflict resolution, Yad Vashem 


\section{Introduction: Problems and Questions}

Over the years Holocaust memory has become increasingly structured around the lessons and legacies of three categories of state (and individual) actors. During the Holocaust one was either a perpetrator (Fascist, Nazis, collaborator, Germany, Europe, the Grand Mufti of Jerusalem), a bystander/voyeur (the USA, neighbors who watched and did nothing, residents living next to the death camps who breathed in the ash-laden air from burning corpses and said nothing) or the victim (Jews in the singular). The memory of this last group has been largely appropriated, contained and nationalised by Israel, most notably as represented by Yad Vashem - The Holocaust Martyrs' and Heroes' Remembrance Authority in Jerusalem.

At Yad Vashem, the destruction of European Jewry is presented today in terms of martyrdom, heroism and resistance; a perspective which is defended in terms of the need for an assertive and defiant self-image as befitting a nation under threat of annihilation. In this national context, 'Never Again!' is understood as first and primarily specifying Jewish victimisation. The Holocaust itself is portrayed as the precondition and necessary event that secured the birth of the state and has thus come to function as the core component of Israel's national identity. The methodology espoused by the Jerusalem-based Holocaust memorial/museum, Yad Vashem is very much in accord with such clearly established political intent. As James E. Young writes:

Of all memorial centres in Israel, only Yad Vashem Martyrs' and Heroes' Remembrance Authority bears the explicit imprimatur of the state. Conceived in the throes of the state's birth and building, Yad Vashem would be regarded from the outset as an integral part of Israel's civic infrastructure. As one of the state's fundamental cornerstones, Yad Vashem would both share and buttress the state's ideals and self-definition (Young, 1993: 243). 
However, there is a problem here. Not all Israeli citizens are Jewish. Today, $20 \%$ of Israeli's citizenry are non-Jews, and of this percentage, $82.1 \%$ are Muslims, $9.4 \%$ are Christians, and $8.4 \%$ are Druze. Thus, like most, Israel is a nation of multi-cultural division. This is a particularly interesting situation because Israel's goal has never been to mediate nor assimilate its (non-Jewish) diversity, but just the opposite. Its wish has always been and remains to this day to in fact achieve non-diversity (a Jewish State for the Jews people) while still maintaining its (self) identity as Western ('the Occident in the Orient'), modern and democratic. In Israel, the Holocaust is evoked as a narrative of victimisation that not only excludes onefifth of its non-Jewish Arab ('Oriental') population but imagines them in a continuum with previous perpetrators.

This is true from the start. In 1953, the Knesset debated and passed the Remembrance of the Holocaust and Heroism Law, known as the Yad Vashem Law (Yom ha-Shoah ve ha-Gevurah). The argumentation in support of this law's passage, by the thenchairperson of the Yad Vashem Committee Mordecai Shenhabi, was framed in what can only be described as a unique form of Zionist Holocaust logic: while the Holocaust was a specific historical event of the Second World War that ended in 1945, at the same time, in Israel, the Holocaust has no real beginning or end. The 1948 War of Independence, Shenhabi reasoned to Knesset members, had been in fact a direct continuation of the war against the Nazis. "The struggle for Jewish survival is ever eternal", he expounded (whether against Germans or Arabs). Yad Vashem's purpose, he promised, would be to impart this lesson to the Jewish nation.

However, these categories began to be contested within the framework of the peace process in the 1990s and they continue being called into question today. The preservation of memory in both victim and perpetrator narratives (the latter most clearly expressed by Europe's 'refugee crisis') has stood firm thus far as countries like Israel and Germany have had to literally and physically, deal with large-scale Arab populations that threaten and contest these absolute identity divides of the perpetrator, victim and by-stander that have been constructed and made into normative foundations of historical identity since the end of the Second World War. From the 1990s there have been three distinct efforts made by Yad Vashem to teach 
the Holocaust to Israel's Arab citizenry. All three programs failed miserably. In this article, I examine the first such attempt in order to identify the underlying causes for Yad Vashem's first educational failure at teaching the Holocaust to its own population during a time that was most advantageous for conflict resolution, 1994-2000. This program could be easily dismissed as a failure because of the outbreak of domestic violence with the Second Intifada in 2000.

My research supports the claim that this failure was, in fact, successful in that the core beliefs that underlie the continuing conflict between Jewish and Arab citizens in the first place were maintained. This failure not only continued the intractable conflict between the majority and minority populations but more during the peace times in Israel in the 1990s. I argue that this intractable conflict did not weaken as a response to the possibility that the conflict might end, instead it became more pronounced and stronger. Various social psychological dynamics contributed to this escalation: selective perception, over commitment, self-fulfilling prophecy, dehumanisation, cognitive rigidity, gamesmanship, and miscommunication. "[W] hat makes these beliefs special in times of intractable conflict is their complimentary wholeness, extremism, black and white view, blind adherence to them, strong belief in their validity and the intensive and extensive use in the society" (Coleman, 2000: 26).

Of course, during the periods of war and conflict, societies and nations can necessarily develop their own narrative(s) to explain the conflict to their advantage and to stand as the only true and morally superior narrative. Such narratives are always morally exclusive (Optow, 2001) and their aim is to devaluate and dehumanise their 'enemy'. If the enemy is morally inferior, in fact, he is immoral with irrational or manipulative, sinister motives. If this is true, then is it logical to assume that in times of peace, the outcome will be different? Do oppose conditions yield opposite results? What if they don't? What if you get the same answer no matter what variables you apply? Should we then deduce this is so because the equation is culturally constructed for only one correct outcome, no matter what the variables are? 
This research rests upon primary sources gathered from Yad Vashem and interviews I conducted with the coordinator and creator of the Arab teachers' curriculum. I interviewed her on two different occasions; the first was on the day before the Sabarro Pizzeria suicide bombing in Jerusalem on 8 August 2001 and the second interview was conducted on the day following that bombing on 10 August 2001. Additionally, educational materials concerning this and other 1990's educational programs of Yad Vashem were gathered and analysed. Here I only examine this educational 19962000 educational program from the perspective of the dominant power in the relationship, the State institution of national narrative/identity, Yad Vashem. I analyse the program within the analytical frame of intractability, employing theories of prominent conflict theorists such as Azar et al., (1978), Bar-Tal (1998), Kriesberg (1995), and Coleman (2000, 2011).

It was not the Middle East Crisis, (as a war between nations) that was intractable. The wars of nations were solvable through diplomacy (The Camp David Accords, The 1994 Peace Treaty with Jordan). The intractable conflict was, in fact, the civil crisis within Israel, between the Jewish and Palestinian Arab Israelis (PAI). This conflict was personal and it boiled down to the essential conflicting paradigm: Who was the victim and who was the perpetrator?

How was this problem dealt with in the curriculum which Yad Vashem had developed? When space opened up for both sides to give voice to their history and realities, it did not lead to a dialogue but a monologue by the majority who retold the minorities' story as one of perpetration, with opportunities for them to choose not to be perpetrators. On the Arab side, the people wanted their history of victimisation by the victims of the Nazis to be considered in the context of their Holocaust learning. Both had long-standing goals that they hoped would be able to achieve in the context of the 1990s. However, they spoke in oppositional voices in pursuit of opposing goals. It appears that the construction of some new hybrid Muslim Jew was not up for consideration; it seems to be the only road to reconciliation. 
With this is mind, there is a core question for both sides: Did you really want them (the other) to change through compromise or did you just want the higher ground? To gain insight into this and other questions raised above, this research is divided into the following five questions as answered by Yad Vashem:

- What were the goals and intentions that informed the curriculum?

- How was the curriculum structured to meet those goals?

- Why Arabs should, or should not study the Holocaust?

Which will then lead to two concluding questions:

- Why is this program considered a failure?

- Was this effort, in fact, a miserable success?

\section{WHAT WERE THE GOALS AND INTENTIONS INFORMING THE CURRICULUM?}

Sovereignty produces and by itself sovereignty was produced through violence, terror and murder. However, political legitimacy is lost unless the State conceals, omits and forgets such crimes. As far as conflict resolution is concerned, perhaps the most harmful approach is when States rationalise their involvement in such matters as a necessity. This is accomplished by creating a narrative of national "goodness" through commemoration (monuments, memorials, and holidays) and narration (history textbooks). Nations do not remember the Holocaust as much as they control it's meaning. Museum collections of cultural memory and historical identity are built to institutionalise federal responses, and representations of, the legitimacy and the moral rightness of the nation.

In the transmission of culture, there is a continual process of reinforcement by which hegemonic culture will add to itself the prerogatives given by its sense of national identity, it's power as an implement ally, or branch of the state, in its rightness, it's exterior forms, and assertions of itself, and most importantly, by its vindicated power as a victor over everything not itself. (Said, 1982:14) 
Yad Vashem's goals for the first curriculum program to teach the Holocaust to Palestinian Arab Israeli (PAI) teachers who were under the State Ministry of Education were overtly ambitious and reflective of State intentions, as listed below.

- To stem anti-Semitism where a strong sentiment runs throughout the Arab world to indicate that Holocaust history is merely a political manipulation, an act of Zionist propaganda, or both.

- To create a connection in the minds of Israeli Arabs today between Jews from the Holocaust and present-day Israelis.

- $\quad$ To disconnect the story of the Palestinian conflict and the story of the Holocaust.

- $\quad$ To dissuade Arabs from the belief that the current

Palestinian situation is not similar to the Jewish tragedy of the past.

- $\quad$ To produce a psychological empathy in the Arabs for the victims that would be transferred to their perceived Israelis of today.

- $\quad$ To claim the exclusive role of victim and to establish the Arabs as perpetrators with the caveat that they can choose to be different than that.

- To make the Arab-Israeli teachers' agents (or "a bridge" as Yad Vashem characterizes characterises their future role) in spreading the state's narrative, as defined above, to other Palestinians.

Thus Yad Vashem wanted to connect, in their PAI audience's minds, Jews from the Holocaust to Israeli Jews of today while at the same time, instructing them to disconnect the Arab/Israeli conflict from the Holocaust. The Arabs or Jews are not the victims of this history. In fact, they were (and perhaps still are) on the side of the perpetrators who sought to destroy the Jewish nation. And as such the best role offered to them in this narrative was to become righteous among the Nations (those that came from the perpetrator cultures but who protected the Jewish life). They should develop empathy for the victims and as such also empathy for their descendants who were only trying to survive in a hostile 
environment of imminent destruction. Taken to its limits, wouldn't such empathy's outcome not be a one-state solution of Arab and Israeli citizens living in harmony? Instead, the necessary conclusions might well be that if you are not Jewish perhaps you should honor the need for a Jewish state by graciously leaving; perhaps something more appropriate like a move to the new Palestinian State agreed upon at Oslo which is on the cusp of becoming a reality? Perhaps they were to be "a bridge between Jewish Israelis and the Palestinians", but perhaps just not in Israel.

\section{HOW WAS THE CURRICULUM STRUCTURED TO MEET THOSE GOALS?}

'Jewish centre for eternalising the Holocaust and its lies?' The correct answer: 'Yad Vashem'.

(A crossword puzzle clue in the official Palestinian Authority newspaper Al-Hayat Al-Jadeeda, 18 February 1999)

Each of the courses for the PAI teachers between 1996 and 2000 was divided into three learning components. The first focused on a discussion of democracy and on answering the question, 'What is a democratic regime?' The aim of this component was to show that Israel is a democracy and that the Nazi state was a terrorist regime. The implied message here is that they too, as Arabs, could choose democracy. The course is described below by its creator, Irit Abramski-Bligh in her words.

Abramski-Bligh: 'What I do is, half of the course, when I have an annual course, we discuss the general concepts of democracy, terror, dictatorial regimes, human rights which apply to anyone. And especially for them. I tried to explain what the Nazi regime is all about. What is Nazi ideology in detail? What is Nazi racism in detail? What is a prevalent idea? What is prejudice? What it is all about? And we discuss it in every society. It is very important that I do not touch the Jewish topic before they really understand what is Nazi regime? What is Nazi ideology? 
My problem for the Arab student is in three types of narratives: we start about how you call it a third part about the sociological workshop about their pain, in general, it just something to open the atmospheres for sincerity. This is the first part. Then we have introduction, and then we have three parts. The first is what is a democratic regime and my goal is to show them to what extent is I am speaking of Israeli Arabs; to what extent they can take advantage of the democracy in Israel and to compare so this is something educationally like...

And what I would like them to understand is that they should pick after all democracy than something else, some other regime, some other regime. That if I... if we were to have a transgression of democracy then it is and lost to everyone -- to them too. And this is the first section of what we discussed in the course. We have films. We have problems which you can see. And I don't do it by myself. Arab teachers help me. And they explain the relevance of tragedies and racism in any society, especially in Arab society. Because there are Arab students who are black in Israel. And there is racism within the Arab society. There are prejudice and sort of racism between Christians and Muslims within the Arabs society. And we touch upon this.

And they say aaah...'It is the same'. So first of all, we explained this.

We discussed Israeli majority and Israeli minority [and] that there is discrimination

And how do they feel where it is a dangerous line we should not cross.

What is natural? What should we avoid?

How to be an educator for tolerant, pluralistic society? How we educate people to be open-minded and to be tolerant even when you are discriminated against?

The second part of the course covers the basic history of the Holocaust, and in the third part of the program, the class examines the reactions of the Arab intellectuals to the Holocaust and to what extent the Holocaust has affected the Arab world. Following this, they discussed the extent of what had happened in Europe had 
influenced the Arab-Israeli conflict. 'Very often, Arabic speakers are unfamiliar with Arabs such as Habib Bourguiba and Idris alSanoussi, and the course helps to create the understanding that not all Arabs saw the interests of Jews and Arabs as diametrically opposed.

I start with the human story where the people are different in every nation. I would say it was my mistake, our mistake, I thought that all the Arabs were homogeneous but in writing my dissertation for seven years I found that the Arabs were mistaken. It is a very good approach. It is very sincere, true. I started from this, and I tell this human story on the intellectual level and political level.

So I have intellectuals. I have politicians. And here, you have it everywhere. And you can choose. If it was possible to choose to make the right choice, then why you can't make the right choice now? I don't say it; I imply it. And that is how I start, and then we discuss with Arab teachers about racism and prejudice and blah blah blah. And what is dictatorial regime? What is democratic regime?

Look, I am in Orientalist by profession. I know this stuff. I know Arabic. I have my PhD in Near Eastern studies, so I know the history. I can, for example, what I use also; I use the Koran. The Koran is very like any religion like the Bible like the New Testament you have dialectics there you have very tolerant you have very extreme you know you have every religion has this kind of stuff: And Mohammed said, for example, the Prophet Mohammed said God created man with two ears two eyes and only one mouth because first he has to listen and then to see and only later speak up.

And you also have jihad in the Koran, but you also have tolerance in the Koran. So why pick this when you can pick that?

And when I say it in Arabic, and I'll bring the Koran, and I bring the interpretation from the Koran in their language. Most of them are religious very religious orthodox Muslims. They believe me.

And I am not inventing anything.

To end the course, instructors would help the teachers to release their own personal pain evoked by the lessons. Then we discuss a little bit also about their Shoah, what you called it. And I disagree using this terminology because Shoah was only one and what they have, they have tragedies, they have disaster, they have whatever 
you want, but not Shoah. The Shoah... the Shoah we know is the one, and we do discuss it we try, and I don't do it myself I do it with Arab teachers as well and actually, after all, they are very grateful because they say this is the only class were we discussed their pain, not only our pain but also their pain. The Jewish instructor refers to this as 'their Shoah. Many do not like this term used in this way, 'the Shoah is only about the Jewish problem,' but it does help make the identification complete' (Abramski-Bligh, 2001, interview).

The historical museum was also used as an educational tool for teaching Arabs. The guidance and the structure of the visit to Yad Vashem are not identical for Jewish and Arab groups. There are special areas of interest that were highlighted for Arab visitors. Guides at Yad Vashem found that Arab visitors often ask, 'Why the Jews?' In order to address this frequent query, at the brief opening exhibit, their attention is directed to the multi-language display of the Protocols of the Learned Elders of Zion to explain that the origins of anti-Semitism predate Hitler and survive (in Arab cultures) to this day.

A poster that greets visitors at the entrance to the historical museum entitled '1945...' often sparks interest among Arabs. Why, they want to know, did so many survivors move to Palestine? Why didn't they just return to their homes in Europe instead of returning to Poland? Their guides explain to them that the Jews had no home to return to after the Nazis were defeated and Palestine was able to accept these displaced victims.

Arabs were also directed to a display that shows the modern clothing German Jews wore, along with a placard explaining that 12,000 Jews died for their German homeland in World War I. The guides use this display to drive home the point that Jews (unlike Palestinians?) were modern people who had neither a political dispute nor any territorial claims on Germany. They were simply citizens who were discriminated against as part of a long history of racism, not because of anything that they themselves had done.

How are Arabs remembered in the museum? The only picture of an Arab in Yard Vashem is the Mufti of Jerusalem meeting Hitler. The implication, of course, being that all Arabs supported Hitler, whereas, in fact, it was the Stern Gang, led by 
former Prime Minister of Israel, Yitzhak Shamir, which offered a military pact to Nazi Germany.

This is ignored while masked as a necessity by the pedagogical director of Yad Vashem at the time, S. Imber:

In general, it is very important to show Arabic-speaking visitors matters of substance - not only posters but also newspapers, children's books, the Hanukkah menorah and the pin (made of nails in the Warsaw ghetto), the bricks from the ghetto walls, the passport bearing the letter "J," and items from the suitcase that a Jew brought with him when banished to the ghetto and the camps. Especially popular are the "toy exhibition" - "No Child's Play" - which illustrates the inner world of the children and their parents. I don't mean teaching anti-Semitism as such. Let's teach about the families (move from intellectual to social/cultural topic of personal identity). Many things you can see as common. What I am trying to do is see the Jew as a person. Why did Anne Frank become universal even though she was Jewish? Identify with the story as a human being. Some people who try to separate Anne Frank from being a Jew is a big mistake... When we go in that direction [the human direction], people are interested. [There] is one purpose, to do just that, keep people interested ... It is not just two hours in history, but it is a story that cuts across that boundary: [a] fluid story that can be sold across the board. There is something that ties students to something larger. And then there is how do we teach about the victims of the Holocaust (Imber, interview 2001).

\section{ANSWERS TO THE QUESTION, "WHY DID THEY COME?"}

During the two different interview sessions I had with AbramskiBligh I asked her repeatedly, consistently and during discussions of very different topics: Why do you think "they" come to Yad Vashem to learn about the Holocaust? At times she responds to PAI teachers, at other times she answers by giving examples of Arabs (citizens 
and non-citizens) and at other times she refers to Palestinians. Below are her 13 responses to the question, "why do they come?" presented in the chronological order they were given during the interviews.

\section{Why do they come?}

1) Abramski-Bligh: It is very important that they know that it is relevant for the Arabs. Because they are interested, because they come, because of their own....

\section{Why they do not come?}

2) Abramski-Bligh: They don't study it unless, until now, perhaps tomorrow? I know they don't. Very few do that. Again the older generation... it is very complex. The older generation tried to avoid it at any price. They don't change. They don't. They are very cautious and... It also it does effect the relations between students and teachers. Because once, before the intifada, the first, teachers were like gods in the class. After the first intifada, the teachers lost their prestige in the eyes of the student in school... because they were collaborators with the Israeli government and they didn't try the Intifada. The leaders of the Intifada were youngsters. The old teachers had to reacquire their position in the classroom. So this topic is very dangerous.

\section{Why do they come?}

3) Abramski-Bligh: Well they don't. Young teachers which young teachers to think about making a career in Israel who want to go to make their PhD's in Germany. They need this in order to be probably even to be against the Israelis. Perhaps I'm doing something which is dangerous for Israeli's interest. Maybe I teach something which will be used against us in the future. I don't know but the young teachers especially those with whom I work with that are part of my stuff the two of them made their PhD's in Germany. Again it is not an accident. I think they find the most friendly state for the Palestinian Arabs to make their PhD.

Because of the Holocaust. Because many neo-Nazis are very happy to find out that the Jews are not so nice. And it's very dangerous and 
very painful for me to overcome those obstacles because everything is propaganda. But when they do it with me sometimes the result is very positive and this I can tell you. Some people When I say ok forget the conflict forget the politics just study the human story.

4) Abramski-Bligh: They were curious. I wouldn't say they came because they...And it's very complicated. The Arab minority in Israel is very, really, now catastrophically but even before the intifada... It is a complicated minority. Because they feel in between like between two fires, between the hammer and the Advil: Between the Arab countries, Arab brethren, Arab Palestinian Authority and the Israeli state. And they feel entangled loyalties, whatever... They don't know. They are confused.

\section{Why they should come.}

5) Abramski-Bligh: In general, most of the Arabs say, my close friends and others, they don't want to leave. And they are not ready to live under the [Palestinian] Authority. They want to stay under Israeli... They want to keep Israeli citizenship. Whatever. So if you are an Israeli citizen, you have to behave... To know something. I mean, you have some responsibility.

You cannot be a declared enemy of the Israeli State. Now, and even if there are a few now that feel like this, [they] still use Israeli medical system, Israeli money, Israeli jobs...I mean...

6) Abramski-Bligh: If you live in a society... I think the young generation of teachers were interested in making a career here. And to understand their Israeli neighbours. They should understand everything, including Holocaust.

7) Abramski-Bligh: Usually they are curious: 'What is this paranoia of those Israelis about the Holocaust'? 'What's it all about'? Perhaps it's all a hoax? Of course, they are very much influenced by the denial of the Holocaust. Because most of them, Internet programs, you know?

They say that Israel uses the Holocaust as a type of manipulation. It is false -- nothing historical. And they are exposed to this kind of 
propaganda. There is no doubt about it. So they are curious. On the one hand... I mean they are confused.

8) Abramski-Bligh: Okay, so there are Arab intellectuals who write articles about the Holocaust. They, not me, they say that every Arab student should study the Holocaust. For the purpose of being knowledgeable. For the purpose of being knowledgeable in Western Civilization. For the purpose of being a cultivated and intellectual person. Ok?

9) Abramski-Bligh: And Edward Said adds that in order to be sincere and reach out and be capable of peace, making peace, you should also speak about pain. So the Israelis should know about the plight of the refugees and the Arab should know about the plight of the Israeli refugees in the Holocaust and this is...

10) Abramski-Bligh: Al-Shabibi says Arabs should learn their lesson; That it was wrong to collaborate with the Nazis. That the Arabs did and it was a wrong step. So all of this belongs to the history of the conflict, of the dialogue, and this is relevant. Simple.

11) Abramski-Bligh: Because they're curious. And they want to say that, what they are trying to say, [is] we didn't learn our lesson. The correct lesson from the Holocaust that we should be we are tolerant towards them because we ourselves suffered what we suffered. So this is the message they are trying to say to the Jewish students. Because they preach what they preach.

So they want to say that the Jews did not learn their lesson. But not all of them. It is very complex. It's not, you; it's not like black-andwhite.

12) Abramski-Bligh: No but they're all kinds, I mean, there all kinds of reactions to the Holocaust. One is negation one is denial. Those people do not come. Okay, forget about them. But even those who have grown oriented to know are curious. They cite this path which is very painful. It is normal. 
13) Abramski-Bligh: No, but they come because they think it is relevant to the general opinions about history, "how to live with the Jews.' They should know.

\section{WHY THE PROGRAM FAILED}

Modernity is constructed from the myth of historical closure, the myth of empathy (that one can put themselves in another's shoes and "feel his pain") and the myth of historical progress. For Walther Benjamin, it is not that events happen repeatedly, but that the world is constantly the same. The old appears as new only because the old has been forgotten. Modernity, writes Benjamin, is not the high point of civilisation, but rather a refinement of barbarism. (Gilloch, 1996: 13)

That the conflict between Jewish and Palestinian/Arab Israelis was (and remains) intractable is well documented and normatively uncontestable. Going into the 1996-2000 program both the majority and the minority came with different truths and historical realities which had up until that point been successful coping mechanisms for them in their conflict with each other: beliefs about the justness of one's own goals, beliefs about delegitimising the opponent, beliefs about positive self-image, beliefs about patriotism, beliefs about unity and beliefs about what peace would look like. These beliefs were so entrenched that had become ideologies, framed as an all or nothing struggle (zero-sum gain) between them. The problem is, that just because the situation changed in the 1990s the actors did not. Such thinking was clearly present in my interviews with the coordinator of Yad Vashem's program for Holocaust education for Arabs. She, for example, describes PAI numerous times in terms like, 'curious', 'confused', in need of civilising and often up to no good. She was often unsure if they the teachers of whom she was speaking were Arabs or Palestinians. They were complex, usable for the State's goals, in need of being responsible citizens if they wished to remain, and in need of educating when it came to being 'modern', 'democratic' and in order to make the 'right choice'. The sort of absolute, win-lose framing that was expressed in the 1996-2000 
curriculum and its program goals was not conducive to compromise or a middle ground.

But that was never the goal, nor was there any real attempt to find a win-win outcome. Instead, both sides spoke at each other rather than with each other. Both sides were more interested in trying to sell their realities based upon different knowledge to the other. Neither side accepted the goals and narrative of the other because their discourses were framed as negations of the very survival of the other.

The reason for the programmes failure was that it was more post-colonial bargaining than it was conflict resolution. Drawing on recent work in the field, Coleman develops eight guidelines for intervening in intractable conflicts. Coleman's fifth guideline directs intervening parties to elicit the conflicting parties' own understandings of conflict and conflict resolution, rather than to impose their own "expert" views. Asking rather than telling is more respectful and empowering, and avoids imposing possibly culturally biased models on the parties. There was no intervention by a third unbiased party to find a solution.

Techniques for dealing with the past include dialogue, having parties reflect on their own role in the conflict and processes of reconciliation and forgiveness. Here this was only done as a "psychological trick" to have the higher ground. Both sides stilled believed that maybe winning was a fuzzy abstraction impossible to conceptualise but no one was unclear what to lose meaning. In addition, culture did not offer support for the teachers to re-(i) manage the past in their classrooms. The chances were high that like teachers before them they would be marginalised by and within their non-Jewish community.

Coming during a decade when a two-state solution seemed a certainty, the goal of the Israelis State remained unchanged, to be the Jewish nation. Those with empathy for the victims, the former perpetrator and by-stander states for PAI teachers their goal was a one state solution where their participation in this learning might be a start to their enjoyment of all the rights privileges and opportunity citizenship in a democracy promises. Yad Vashem was teaching them to leave and be a bridge in the future. They were learning to have a better life in Israel without forgetting their own victimisation. 
In $197621.5 \%$ of n-JAIs, Sammy Smooch surveyed rejected Israel's right to exist. By 1995 that number fell to $6.8 \%$ and, related to the second Intifada, rose to $10.2 \%$ in 2003 . When asked if they supported the use of violence to improve their condition in Israel, $17.9 \%$ of those surveyed said yes in 1976, 6\% in 1995 and only $3.1 \%$ in 2003. When asked if they defined their identity as a Palestinian devoid of an Israeli component 32.9\% $10.3 \%$ and 5.6\% said yes in 1976, 1995 and 2003 respectively. Such data does not support the State's hypochondriac death fantasies nor warrant the need to do violence to the body in order to remove some life-threatening condition. Smooch's finding illustrates that the data on n-JAIs does not conform to the radicalisation thesis. (Smoocha, 2004).

It would be easy to assume that such differences can best be understood as the logical outcome of the politics of their times. The 1990s program was created during a period of impending peace between Israel and the Palestinians. And while it is true that the first program was conceptualized during Rabin's government, when the Ministry of Education was headed by the Meretz Party that did, in fact, have a pro-Arab inclusionary view, to think that this program was sired from this particular political climate or was the product of this particular and limited timeframe would be short sight indeed. Holocaust education for PAI teachers was never a project contested by any of the extremely different political parties, or politicians of different generations, which came to power following Rabin, (Peres, Netanyahu, Barak, and Sharon). What can be said is that the purpose and goals of the Arab teacher education program were accepted by all political parties, were longstanding and were twofold: security of the state (from a radicalised Arab citizenry) and the maintenance of a Jewish nation (a growing demographic challenge). Every population remaining in Israel's borders became a minority after the 1948 Civil War numbering a mere 156 000. 60 years later this indigenous ethnic minority has multiplied ten times and in 2009 numbered 1.7 million excluding the population of the Golan Heights and East Jerusalem constituting 20\% of Israel's population.

Arab teacher participated in 1996 for reasons of professional advancement and national integration. Integration was seen as the logical next step in their personal and collective development. Because of high unemployment rates among educated PAIs, many turned to teaching as an attractive strategy for social and even 
political mobility. PAI teachers were moderates with middle-class intentions who had repeatedly been vetted for extremism and were overtly controlled by the State. They were comfortable negotiating the multiple identities that defined who they were and as such viewed the State in a functionalist liberal role as a just agent of modernization, representing middle-class interest (Swiraki, 1999). Educational equality was a top priority of the Palestinian civil rights struggle in Israel, and the school was the symbol, their battleground, to participate in Israel's declared democracy and dedication to equality. The problem here is that educational policy as well as the public debate on education was exclusively an intra-Jewish matter evaluated solely by its contribution to the Zionist nation-building effort. Concerning the topic of Arab education and Holocaust education, in particular, there was never any mention of crossnational integration. Successive Israeli governments have consistently declined to either treat Palestinian citizens as equal to Jewish citizens or to recognize the Palestinians as a distinct cultural a national minority entitled to minority rights. Equality was not the State's goal in 19996. It was the Arabs' goal.

By the 1990s, Yad Vashem had adopted a new approach to teaching the Holocaust. Pedagogically, Yad Vashem adopted a more personal approach in its teaching method described as, "putting a face on history". While the messages of heroism and martyrdom remain the same, Yad Vashem's new approach adjusted itself to public tastes by accentuating personal stories in order to raise larger questions about universal values. This teaching method was adopted from the United States Holocaust Memorial Museum where it was very successfully employed to create empathy for Jewish victims and to reinforced ideas of democracy and to" Never Again" be bystanders to genocide. This approach also worked well in perpetrator narratives. In both narratives, Jewish victimisation is empathically lamented. This teaching approach had very positive results with all groups but one: Palestinians because this is the one group that contests which are the real victims of the Holocaust. At the core of the conflict is who gets to be the victim and who is the perpetrator. This competing victimisation prevented either side from achieving their intended goals. 
When the first teacher participated in this course, what happened in the program was unexpected. Instead of sitting through lecture passively listening, they were being listened to. The first program assigned Arabs the role of helpers and supports of the Jews. In order to produce a feeling of empathy from their audience, Yad Vashem allowed them to speak of al-Nakba and their frustrations they felt toward the State. The point of this was that this exercise was that they would then be open to the victimisation of the Jewish people. But something went wrong with this teaching methodology. Arab teachers did not move past the connection and what emerged was their feeling that they were victims not only of the Germans but also of Israel as an agent of Western colonialism. The 1996 program was a failure because these teachers saw the connection between the al-Nakba and the Holocaust as equal tragedies (Sholam, 2003).

As Nietzsche explained, "You can explain the past only by what is most powerful in the present." The prominence of a collective memory, therefore, is a reflection of the social role of a particular group. In recollection, we do not retrieve images of the past as they were originally perceived but rather as they fit into our present conceptions, which are shaped by the social forces that act on us. The ruling class, Antonio Gramsci writes, rules because they make their interests seem "natural" and "universalistic". Hegemony is achieved when the ruling classes used political and military control to maintain power while employing cultural means to express their right to that power.

However, the Arab audience in these programs experienced the learning process through their own lens. "The visitor's personal context is perhaps the single greatest influence on the visitor's museum experience, and perhaps the most important manifestation of the personal context is the visitor's agenda." (Falk, 1992: 37). Observation of visitors examining information in exhibitions shows that visitors try, often quite desperately, to relate what they are seeing to their own experiences (ibid.: 74). In the footsteps of Walter Benjamin, Chris Rojek believes that "myth and fantasy play an unusually large role in the social construction of all ... sights". For Rojek, it is not the question of reality that determines authenticity but the spontaneous emotion at work in its reading (Rojek, 1997). 
In this way, the traditional Orient/Occident divide anchors the conflict. In his book, Orientalism (1982) Edward Said identified a dichotomize discourse that supports an inherently superior West (the Occident) that is juxtaposed with an inferior eastern "other" (the Orient) according to terms and definitions determined by the West itself. Orientalism has created an image of the Orient as separate, backward, different, irrational and passive. The Orient is characterized by despotism and resistance to progress, non-secular and since Oriental values are judged in terms of and a comparison to the west, it is always viewed as the other, the conquerable, and the inferior. The Orient (here n-JAIs) is perceived as relatively inhospitable to democracy and that inhospitality, in turn, nurtures conditions favourable to parochialism, anti-modernism, exclusiveness and hostility to 'others', "the characteristics that constitute Jihad (Barber, 1996:205). Arabs saw the early Zionist settlers as agents of European oppression. Palestinians encountered them as colonial settlers. How did Palestinians encounter Jew during colonial period and Holocaust survivors after statehood? The fact that 22,000 soldiers, or a third of the Haganah during the 1948 war, were Holocaust survivors is important as they participated in the expulsion of Palestinians and the many massacres of the 1948 war (Segev, 177). Zionist settlers would rely on European protection, clinging to their European passports and invoking the intervention of European diplomatic agents. To the extent that Zionism saw any role for Palestine in its ideological project, it was to have them internalise Zionism's version of their history and appreciate its "civilising" mission.

It is easy to see the practice of Israel through a post-colonial lens of Israel is an evil coloniser. But isn't it just as true that the Arabs were also colonial agents of the Orient (Nazi Europe)? Both used connects with different sides of the west during the war, and the Arab side (Nazi Germany) lost the fight. Colonialism, at its very conception, involves a series of concerted actions to destroy the very foundations of the life of the oppressed group (the colonised) while attempting to replace them with the national pattern of the colonisers. Important to this consciousness is the philosophical myth of history that ranks other societies by reference to western values posing as universal norms (Delanty, 1984: 95). These ideas 
of moral superiority of western civilisation are used as an ideological justification for the conflict and for not compromising the rightness of one's position concerning the "civilising" process.

But I think it is too easy to see this division as created by ideas of the Orient and the Occident. In the Arcades Project (1927 and 1929), Walter Benjamin's provides a surrealist reading of the fantasy content of everyday life. Like the Surrealist, he sees culture as suffused with the direct expression of the unconscious. Wish fulfilment and repression are integral to the processes of reality formation. The museum is not only a showplace for commodities; it is also a material register of our inner fantasies and dreams. Said's point was that Orientalism was a form of ideological fantasy, with no necessary relation to the actual cultures that it supposedly described and understood: the very Orient was itself an Orientalist fiction. That fantasy needed to be stretched into a belief in a better future than then one they imagined.

This was not done but perhaps was possible, theoretically. Man's will to believe in a better future is the core philosophical ideal of James pragmatism. The future is only a belief, but James claims that 'belief creates its verification [and] becomes literally father to the fact'. Thus the problem was there was no belief in any future, but the one they held and thus a new possibility was not produced. Future-oriented techniques include using focused social imaging to create a vision of a better future state and sustainable reconciliation processes for rebuilding relationships and addressing structural injustice. On both sides, there are traumatised individuals and people who are in psychological crisis as a normal condition.

In the end what they shared was what divided them: In a broader sense, since all of the injured self-images that parents in a large traumatised group transmit to their children referred to the same event, a shared mental representation of the tragedy develops. By sharing this representation of their ancestors' trauma, a new generation of the group is unconsciously united. Once a shared trauma becomes a chosen trauma, its representation can become as important as the original event itself. Rituals around the chosen trauma, such as remembrance days or moments of silence, are developed to shore up or strengthen large-group identity. This does not mean that the victimised group chose to be traumatised; instead, it reflects the group's unconscious 'choice' to add a past generation's 
mental representation of an event to its own identity. In the words of Vamik D. Volkan, 'A chosen trauma is linked to the past generation's inability to mourn losses after experiencing a shared traumatic event and indicates the group's failure to reverse narcissistic injury and humiliation' (Volkan, 1991, 1992, 1997; Volkan and Itzkowitz 1993, 1994).

Interestingly, a chosen trauma may change function as it passes from one generation to another (Apprey, 1987). In one generation, the trauma may support the large-group identity as a victimised group. For another generation, it may support a selfimage of strength and moral rightness. Whenever a new ethnic, national or religious crisis develops for the group, its leaders will intuitively rekindle memories of past chosen traumas so as to consolidate the group emotionally and ideologically. When feelings, perceptions, and anxieties about a past wrong or trauma become compressed into feelings, perceptions and anxieties about current events, this process is known as time collapse (Volkan, 2000).

I think these ideas and Yad Vashem's approach has no chance of success what so ever.

\section{Conclusions: A Miserable SuCCESs?}

Although many Arabs are aware of the historic tragedy that befell their Jewish neighbours but are often muted in expressing their sympathy due to the bitterness of the conflict or out of a conviction that it will be used as a political weapon against them. "Many Palestinians feel that sympathising too much with Israelis could lead to justification for the occupation," the BBC as saying once quoted Sami Adwan, a professor of education at Bethlehem University.

When looking at the context in which the program was created, the reasons for its creation, its goals, methodology and desired outcomes it is very obvious that there was no hope for any real attempt at dialogue and conflict resolution through The Holocaust for Arab Israeli Teachers. Yad Vashem insists that the fundamentals of teaching Holocaust history are the same whether the target population is Jewish or Arabic. However, if you take a broader view at the intentionally and purpose of the programs, a different perspective emerges. 
In, The Origins of Totalitarianism (1984) Hannah Arendt contextualised the Final Solution within a pattern of European colonial expansion and mono-cultural domination. Colonialism at its very conception involved a series of concerted actions to destroy the very foundations of the life of the oppressed group (the colonised) while attempting to replace them with the national pattern of the colonisers. Important to this consciousness was the philosophical myth of history that ranked other societies by reference to western values posing as universal norms (Delanty, 1984: 95). These ideas of moral superiority of western civilisation were used as an ideological justification for colonialism.

Their exchange between Yad Vashem and Arabs goes only one-way: Arab part of the story is omitted. This is neo-colonial in nature The Palestinians wished to introduce the Israelis to al-Nakba (the Arabic for "The Catastrophe"), which is the term Palestinians use to describe perhaps the most defining trauma in their national experience: the exodus of up to three-quarters of Palestine's Arab population, most of whom were not allowed to return following Israel's Declaration of Independence in 1948.

However, they lamented the absence of a museum chronicling this painful chapter of Palestinian history. Some Palestinians suggested that the Israelis should join them on a trip to a refugee camp to enable them to gain a deeper insight into what contemporary life is like for many Palestinians. "I want to introduce our Jewish friends to the suffering of the Palestinians... Just as they told us about their suffering in detail from an Israeli perspective, I'd like them to hear all the details about our stories," reflected Mutasem Halawani, a student of business management from Jerusalem. "This helps build an exchange of ideas and tolerance."

Yad Vashem claims that their Arab program uses the same materials and curriculum as were used in all their educational programs is questionable. For Jewish students and especially in Yad Vashem's Holocaust education program with the military, the connection between the Holocaust and the Arab Israeli conflict is a goal. 
When Education Minister Ben-Zion Dinur introduced the Yad Vashem Law in the Knesset in 1953, he made clear the connection between the Holocaust and the State of Israel. The War of Independence was connected to the war against the Nazis. The Holocaust became a state of mind.

In the winter of 2001, the General Staff of the Israeli Defense Forces held a special meeting to discuss that lessons that could be learned from the Holocaust. The generals met in a conference room at Yad Vashem, and their meeting was closed to the media. The question on the table was whether the heritage of the Holocaust was "beneficial or harmful, essential or superfluous, for soldiers who are now called upon to suppress the Intifada." The position of the members from the left was that the Holocaust could serve as a restraining factor, while those on the right advocated the Holocaust as a "steeling" factor (Segev, 2002:1). No matter which side, it went without question that the Holocaust and the current conflict was a factor.

This debate on the meaning and purpose of the Holocaust shapes and underpins the institutions' authority in the field of educational curriculum. These museums-memorials stand at the forefront of funding major research projects, organizing international conferences, as well as serving as major archive depositories and curriculum production. The museum cannot be separated from the classroom. The narrative of one is the point of departure of the other.

James Young wrote that memory is never shaped in a vacuum; motives of memory are never pure (Young, 1993: 2). In order for an event to take a permanent place in history textbooks or museums, it must be accepted by both professionals and the general audience as authorised, or in Thomas Kuhn's phrase, 'normative' (Kuhn, 1996). How a historical event is 'packaged', and then ultimately 'bought' as normative or authorised is complex. Governments and ethnic and national groups are sensitive to how their story is portrayed in fiction, reportage, and scholarship. They sometimes are willing to use extraordinary means to stop a representation of themselves not to their approval through censorship, lies, violence, and other means. 
In Imagined Communities, Benedict Anderson (1991) emphasises the imagined nature of nationalism. He argues that nationalism is a uniquely modern phenomenon, which creates a new consciousness. He also suggests that nationalism is sometimes invented to overcome perceived injustices and mobilise communities against such injustices. Of course, one element critical to the construction of a national image is that citizens find evidence for their sense of a nation in the legends and myths out of which national identity is constructed (or, to use Anderson's term, imagined).

The ruling classes, Antonio Gramsci wrote in The Prison Notebooks (1971), rules because they make their interests seem 'natural' and universalist. He developed the notion of 'hegemony' that explains how the ruling classes use the political and military control to maintain power while employing cultural means to express their right to that power. When we consider the nature and functions of museums in general, we may recognise and acknowledge their educative purpose, but this tends to be a subtext of a more explicit intent to collect and preserve particular cultural artefacts and icons. Thus, for example, the main text of an institution such as the British Museum may be presented in a neutral guise as the protector and restorer of world antiquities, curiosities, and artefacts. At the same time, however, and as part of the museum's educative function in the creation of cultural capital, there is a masking of western 'civilization's' hegemony, and pillaging of dominated cultures so as to secure the artifacts and prove other (read 'lesser') cultures' debt and indebtedness.

It is somewhat different in the case of museums and memorials dedicated to the event known as 'The Holocaust'. Here, arguably, the text and subtext of museums are reversed in that the primary purpose is educative, and this, in turn, is served by the purposeful selection and preservation of records and artefacts to support an educational agenda. If we acknowledge that the museums and memorials of the Holocaust have taken on a fully legitimised function as educational institutions, then we can, and should, legitimately ask questions regarding their curriculum, methods, and means of presentation and their social-political intent. In other words, we need to reconsider these places as educational institutions with specific social, cultural, economic, and national agendas. 
It is not a question of whether people are moved by a museum, but of how they are moved. To what ends have they been moved, to what historical conclusion, to what understanding and actions in their own lives? The relationship of citizens to the State is determined through ideology, and one of the most important mechanisms of that relationship consists of the construction, perception and presentation of the imagined community within popular, political and ideological discourses. The Shoah has become such a reference. It consists of both imaginary and practical elements that depend upon each other for their meaning. It functions as an effective symbol for the evocation of, among other things, particular historical traditions in different countries. Martin Broszat wrote that monuments might not remember events so much as bury them all together beneath layers of national myths and explanations. They coarsen historical understanding as much as they generate it (Broszat, 1988: 90-91).

\section{References}

Personal interviews

Irit Abramski-Bligh, August, 2001

Shulamit Imber, August, 2001

Abramski, I. and Keich, H. (1999). Teaching the Holocaust to the Israeli Arabs. Speech 14 October 1999.

Adwan, S. \& Firer, R. (1997). The Narrative of Palestinian Refugees During the War of 1948 in Israeli and Palestinian History and Civic Education Textbooks. Paris: UNESCO.

Adwan, S and Firer, R. (1999). The Narrative of the 1967 war in the Israeli and Palestinian History and Civics Textbooks and Curricula Statement. Braunschwieg, Germany: Eckert Institute.

Albeck, J.H., Adwan, S. \& Bar-On, D. (2002). Dialogue Groups: TRT's Guidelines for Working Through Intractable Conflicts by Personal Storytelling in Encounter Groups. Journal of Peace Psychology, 8 (4): 301-322. 
Al-Ashmawi, F. (1996). The Image of the Other as Presented in

History Booklet. International Textbooks Research, 18

(2):221-229. Braunschwieg, Germany: Eckert Institute.

Al-hayat Al Jadeeda. 18 February 1999. Crossword puzzle.

Anderson, Benedict (1991). Imagined Communities: Reflections on

the Origin and Spread of Nationalism. London: Verso.

Angvik, M. \& von Borries, B. (Eds.) (1997). Youth and History: A

Comparative European Survey on Historical ConsciousnesS and Political Attitudes among Adolescents. Hamburg: Koerber Foundation.

Apple, M.W. (1979). Ideology and Curriculum. London: Routledge \& Kegan Paul.

Apprey, M. (1987). 'Projective identification and maternal misconception in disturbed mothers'. British Journal of Psychotherapy4: 5-22.

Arendt, Hannah (1984). The Origins of Totalitarianism. New York: Schoeken.

Bar-On, D. (1999). The Others Within Us: Changes in the Israeli

Collective Identity from a Social Psychological Perspective.

Ben Gurion University Press \& Mosad Bialik.

Benjamin, W. (1985). Illuminations: Essays and Reflections.

Hannah Arendt (Ed.). New York: Schocken Books.

Benjamin, W. (1999). Arcades Project. Howard Eiland and Kevin McLaughlin (Eds. and Trans.). New York: Belknap Press.

Bennett, T. (1995). The Birth of the Museum: History, Theory, Politics. New York and London: Routledge.

Bar-Tal, D. (1995). The Rocky Road toward Peace: Societal Beliefs in Times of Intractable Conflict: The Israeli Case. Jerusalem: The Hebrew University, School of Education.

Bar-Tal, D. (2013). Intractable conflicts: Socio-psychological foundations and dynamics. Cambridge: Cambridge University Press.

Bar-Tal, D. (2007). Living with the conflict: Socio-psychological analysis of the Israeli-Jewish society. Jerusalem: Carmel.

Bar-Tal, D., \& Teichman Y. (2005). Stereotypes and prejudice in conflict: Representations of Arabs in Israeli Jewish society. Cambridge: Cambridge University Press. 
Bourdieu, P. (1973). Cultural Reproduction and Social Reproduction. In R. Brown (Ed.), Knowledge, Education and Cultural Change. (71-112). London: Tavistock.

Broszat, Martin, and Saul Friedländer. "A Controversy about the Historicization of National Socialism," Yad Vashem

Studies 19 (Fall 1988): 1-47.

De Graaf, T. (1975). Pathological Patterns of Identification in Families of Survivors of the Holocaust in Israel Annals of Psychiatry and Related Disciplines, 13: 335-363.

Delanty, Gerard (1984). Inventing Europe: Idea, Identity, Reality. New York and London: Palgrave Macmillan, Basingstoke.

Falk, John H. (1992) The Museum Experience, Washington, D.C.: Whalesback Books.

Gilloch, G. (1996). Walter Benjamin: Critical Constellations. London: Polity.

Gramsci, Antonio (1971). Selections from the Prison Notebooks. Quintin Hoare and Geoffrey Nowell-Smith (Eds.). New York: International Publishers.

Halbwachs, M. (1992) On Collective Memory. Ed. and trans. Lewis A. Coser. Chicago: University of Chicago Press.

Hartman, G. H. (1994) (Ed.). Holocaust Remembrance: The Shapes of Memory. Oxford and Cambridge, MA:

Harvard University Press.

Hyman, P. (1980). 'New Debate on the Holocaust'. New York Times, 14 September 1980: 79.

Imber, S. (2001). 'How to Teach Moral Values and Tolerance from the History of the Holocaust'. Speech at the Stockholm International Forum.

IPCRI report (2003). Analysis and Evaluation of the New Palestinian Curriculum. Submitted to the USA Public Affairs Office, US Consulate General, Jerusalem, March, 2003.

James, W.(1896.) The Will to Believe and other Essays, Popular Philosophy (1896)

Kuhn, Thomas (1996). The Structure of Scientific Revolutions. Chicago: University of Chicago Press.

Lentin, Ronit (2004). Re-Presenting the Shoah for the 21st Century. Oxford and New York: Berghahn Books. 
Maoz, I. (2000a). 'Power Relations in Inter-Group Encounters: A Case Study of Jewish-Arab Encounters in Israel'. International Journal of Intercultural Relations, 24, 259277.

Maoz, I. (2000b). 'Multiple Conflicts and Competing Agendas: A Framework for Conceptualizing Structured Encounters between Groups in Conflict: The Case of a Coexistence Project between Jews and Palestinians in Israel'. Journal of Peace Psychology, 6, 135-156.

Maoz, I. (2000c). 'An Experiment in Peace: Reconciliation-aimed Dialogues of Israeli and Palestinian Youth'. Journal of Peace Research, 37, 721-736.

Milson, Menahem (2003). Countering Arab Anti-Semitism. Jerusalem: Institute of the World Jewish Congress.

Nave, E., \& Yogev, E. (2002). Histories: Towards a Dialogue with Yesterday. Dafna Danon (Ed.). Tel-Aviv: Bavel.

Opotow, S. (2001). Moral Inclusion and the Process of Social Reconciliation. Social Justice Research, 14, 2, 149-170.

Ritzer, G. and Allan L. (1997). 'Complementary Perspectives on Contemporary Tourism'. In John Urry and Chris Rojek (Eds.) Touring Cultures: Transformations of Travel and Theory. London: Routledge.

Rojek, C. (1997). 'Indexing and Dragging'. Chris Rojek and John Urry (Eds.). Touring Cultures: Transformations of Travel and Theory. London: Routledge.

Said, E. (1982). Orientalism. New York: Vintage.

Segev, T. (1994). The Seventh Million: The Israelis and the Holocaust. New York: Henry Holt.

Segev, T. (2001). "Genocide, A Modern Sickness: Israel and the Memory of the Holocaust." Le Monde Diplomatique. 13 April 2001. English online edition.

Segev, T. (2002). "Nazis, Nazis." In The Seventh Million: The Israelis and the Holocaust. New York: Holt.

Shehori, F. (October 1999). 'Holocaust Education and the Isreali (sic) Defense Forces,' Yad Vashem Conference on Education, Jerusalem.

Shoham, E. (2003) Arab teachers and Holocaust education: Arab teachers study Holocaust education in Israel. Teaching and Teacher Education. 19 (6): 609-625. 
Smooha, S. (2007). Arab-Jewish Relations: Index 2006: New Data Regarding the Status of a Palestinian-Arab Minority in a Jewish and Democratic State. In Whose Responsibility Is This? The Second Haifa Conference for Social Responsibility 2007. Haifa: University of Haifa.

Steinberg, S. \& Bar-On, D. (2002). 'An Analysis of the Group Process in Encounters between Jews and Palestinians Using a Typology for Discourse Classification'. International Journal of Intercultural Relations, 26, 199-214.

Tawil, S., Harley, A. \& Porteous, L. (2003). Curriculum Change and Social Cohesion in Conflict-Affected Societies. Geneva: UNESCO.

Levi, D. (1987). The Dynamics of Agenda Building: Case Study Reform in Israel's educational system. MA thesis, Department of Political Science, University of Haifa.

Swirski, S. (1999). Politics and education in Israel: Comparison with the United States. New York: Falmer Press.

Volkan, V. (1997.) 'Ancient Fuel for a Modern Info: Time Collapse in Bosnia-Herzegovina." Vamik Volkan (Ed.). Bloodlines. New York: Farrar, Strauss and Giroux.

Volkan, V. (1999). "Psychoanalysis and Diplomacy: Part I. Individual and Large Group Identity." Journal of Applied Psychoanalysis Studies 1, 1.

Volkan, V. (2005). "Large Group Identity and Chosen Trauma." Psychoanalysis Downunder, 6 (December 2005).

Yablonka, H. (2003). 'The Development of Holocaust Consciousness in Israel: The Nuremberg, Kapos, Kastner, and Eichmann Trials'. Israel Studies 8 (3):1-24.

Young, J. E. (1993). The Texture of Memory. New Haven: Yale University Press.

Young, J. E. (1994). The Art of Memory: Holocaust Memorials in History. New York and Munich: Prestel Verlag. 